\title{
Interstícios do Cativeiro: um caso em Iguaçú na crise da escravidão ${ }^{1}$
}

\section{Leonardo Marques ${ }^{2}$}

Resumo: Partindo de um processo cível como fonte central, procuro levantar algumas questões importantes relacionadas às relações escravistas no Paraná e buscar algumas hipóteses e sugestões sobre o destino de libertos após a abolição. Cruzei os dados deste processo com outras fontes, como doações testamentárias de senhores à seus cativos, bem como com alguns dados das listas de classificação realizadas para serem utilizadas por um fundo de libertação dos escravos criado em 1872. Alguns pontos-chave discutidos no trabalho foram: a existência da família escrava no Paraná e como as características dessa região influenciaram na mesma; a existência de doações e alforrias como a ponta de um sistema de incentivos senhoriais ligado ao paternalismo permeando a sociedade; a convivência de escravos, libertos e livres, bem como os significados da liberdade neste momento de crise da escravidão.

Palavras-chave: Escravidão, campesinato, Paraná - século XIX.

\section{Introdução:}

Qual terá sido a reação de Vicência ao receber a intimação do oficial de justiça em dezembro de 1888 ? Ela e seu marido Gabriel estavam sendo chamados para comparecer às audiências em torno de uma ação movida por Sebastião Pereira dos Santos e sua mulher. A intimação foi dirigida apenas à Vicência por seu marido "achar-se além do Rio Preto, distrito de São Bento". A região em que reside o casal é Rio Negro, parte da comarca de Lapa na época. Dali a alguns meses recebia igual intimação José Pinheiro - filho de Gabriel e Vicência - e sua mulher Luzia de Oliveira, também residentes em Rio Negro, mais especificamente na região do "Espigão do Bugre". Em Iguassú, parte da Comarca de Curitiba, por fim, Maria recebia um oficial de justiça com função semelhante aos anteriores

\footnotetext{
${ }^{1}$ Trabalho desenvolvido no PET ao longo do ano de 2003.

${ }^{2}$ Graduação História - UFPR
} 
mencionados. O elo entre estas pessoas é um passado comum que agora retornava na forma de um processo.

Há alguns anos, Gabriel, Vicência, José Oliveira e Maria eram o plantel de escravos de Mariano Cardoso, na região do Iguassú. Em 1880, meses antes de sua morte, Mariano deixava um testamento no qual afirmava: "declaro que a minha mulher Rosa Ferreira dos Santos gozará do usufruto dos bens que the couber durante sua vida e depois de seu falecimento serão divididos a meus escravos com igualdade". Rosa Ferreira dos Santos, a senhora que recebeu estes bens - inclusos aí, obviamente, os quatro escravos - era a mulher que agora, em 1888, movia esta ação ao lado de Sebastião Pereira dos Santos, com quem havia contraído um segundo matrimônio.

A ação de libelo civil movida pelo casal contra os ex-escravos de Rosa tinha como intenção primeira considerar sem efeito o legado deixado pelo falecido marido da senhora. Quando de sua morte, Mariano provavelmente não contava com o segundo casamento de sua mulher, e esta, agora com uma nova família, naturalmente preocupava-se com o destino dos bens de seu primeiro matrimônio. Em face disso, parece mais lógica sua luta na justiça para invalidar aquele testamento. Conseqüentemente, aqueles ex-escravos tinham suas presenças requisitadas nas Câmaras para conciliar-se, ou não, com sua ex-senhora.

A análise do processo em questão possibilita discussões de mais largo escopo como aquelas relacionadas a este período final da escravidão bem como outras relativas ao período pós-abolição. $\mathrm{O}$ fato do processo evidenciar migrações de cativos pode estar revelando expectativas dos escravos, sendo que estas são importantes para que compreendamos as trajetórias após o fim da escravidão.

Neste sentido, é crucial discutir o processo ao lado de bibliografia referente a estes temas buscando atentar, entretanto, para certas particularidades da escravidão paranaense e suas conseqüências para o pósabolição na região. Esta discussão de maior alcance é necessária, também, pela escassez de pesquisas em torno destes temas, em especial no que se refere a estes momentos após a abolição, para o Paraná. As produções mais recentes em torno da escravidão paranaense têm crescido, mas param em 1888, caso do trabalho "O Jogo da Face", de Eduardo Spiller Pena, que estarei utilizando ao longo deste texto. Outros artigos e teses têm sido produzidos, mas ainda fica esta lacuna para os momentos pós-abolição. A escassez de estudos do tema se dá, também, por certas especificidades das fontes do período posterior a 1888 , que não se referem à cor, característica 
problematizada por Hebe $\mathrm{Mattos}^{3}$, o que acaba por dificultar o trabalho dos pesquisadores. Entretanto, o tema é do mais profundo interesse e cabe a nós estabelecermos estratégias de utilização das fontes que possibilite-nos arrancar o máximo de impressões, que por sua vez suscitem cada vez mais debates sobre este processo.

Já há algum tempo uma excelente historiografia acerca da escravidão vem buscando analisar os escravos enquanto sujeitos e não simplesmente objetos totalmente desprovidos de desejos que sofreram a ação implacável de uma eficiente máquina chamada escravidão. A crítica empreendida por diversos autores vai na direção de buscar olhar para estes escravos, suas práticas e aspirações, como os estudos que vêm demonstrando a existência da família escrava - bem como seu modo de organização e questões a que ela respondia ${ }^{4}$ - fato este negado por esta geração de pesquisadores que ficou mais conhecida como a Escola Sociológica Paulista.

Para que encaremos os libertos após a abolição como sujeitos é interessante levar em conta a sugestão de Giovanni Levi em se buscar uma racionalidade específica das pessoas e grupos em questão, pois "uma racionalidade seletiva e limitada explica os comportamentos individuais como fruto do compromisso entre um comportamento subjetivamente desejado e aquele socialmente exigido, entre liberdade e constrição" ${ }^{5}$. O presente trabalho se constitui em um esforço para se captar algo destas questões que estavam em jogo: pressões sociais em torno da questão do trabalho e aspirações destes ex-escravos, buscando tratá-los como sujeitos com intenções e incertezas frente à situação que se afigurava. Sempre considerando, também, as caracteristicas da sociedade em que viviam e como seus projetos articulavam-se à elas.

\section{A produção de dependentes:}

O ponto de partida de nosso caso é, portanto, uma doação feita em testamento, transcrito ao longo do processo cível. Mariano Cardozo deixava

\footnotetext{
${ }^{3}$ MATTOS, H.M. Das Cores do Silêncio: os significados da liberdade no Sudeste escravista, Brasil Século IXI. Rio de Janeiro: Nova Fronteira, 1998.

${ }^{4}$ Dois livros que vêm suscitando ótimos debates nesta área são "Na Senzala uma Flor" de Robert Slenes e "Paz nas Senzalas" de Manolo Florentino e José Roberto Góes presentes na bibliografia.

${ }^{5}$ LEVI, G.A herança imaterial: trajetória de um exorcista no Piemonte do século XVII. Rio de Janeiro: Civilização Brasileira, 2000, p. 46.
} 
todos os seus bens a sua mulher e quando esta falecesse tudo seria repartido igualmente entre seus escravos. Tal ato não era uma aberração na história da escravidão brasileira e insere-se em uma lógica que estrutura as relações de dominação escravista.

Como diz Hebe Mattos, "a reiterada produção de dependentes, nesta sociedade, estava assim referida a todo um sistema cultural que, mesmo diferentemente apropriado por dominantes e dominados, era comum a todos e informava suas expectativas em relação à liberdade" ${ }^{6}$. Permeava a sociedade e envolvia não apenas senhores e escravos, mas nascidos livres, libertos, em suma, a todos. Tendo em vista esta característica central, tornase mais fácil a compreensão de atitudes que poderiam parecer, a primeira vista, paradoxais, como alforrias e doações testamentárias.

O fato da doação aqui tratada ser da década de 1880 , poderia levar-nos a considerá-la conseqüência de um período de desagregação da escravidão. Entretanto, o que buscaremos aqui mostrar é que, pelo contrário, tal doação nos parece estar muito mais ligada à legitimação da escravidão.

Rejeitando a idéia de uma bondade inerente a estes senhores que fizeram doações como a aqui analisada, ou de uma escravidão mais suave que poderia caracterizar o caso brasileiro, Robert Slenes levanta algumas hipóteses importantes. $\mathrm{O}$ autor argumenta na direção de que estes testamentos garantindo a liberdade e a doação de bens a cativos seria como que a ponta de um iceberg, entendendo este como um sistema de incentivos senhoriais. Eles seriam frutos da própria dinâmica da escravidão. Apesar de trabalhar com o Sudeste, mais especificamente a região de Sorocaba, seu estudo dá algumas indicações interessantes sobre a doação aqui analisada.

Seguindo esta idéia de que as doações servem a uma lógica de "produção de dependentes" ?, Slenes vai destacar algumas características que se evidenciaram em sua análise da documentação, composta por 89 testamentos. Dois pontos foram centrais: a maior parte dos escravos contemplados com alforria e terras possuiam familias estáveis e os doadores buscavam impedir que os ex-escravos alienassem a propriedade. Estas duas constantes "sugerem uma política por parte desses senhores visando a transformar seus escravos em 'dependentes'. Isto é, ofereciam-se condições de estabilidade (favoráveis à formação de famílias), a proteção devida a clientes menores e eventualmente o prêmio da alforria, ou da liberdade com

\footnotetext{
${ }^{6}$ MATTOS, H.M. Das Cores do Silêncio: os significados da liberdade no Sudeste escravista, Brasil Século IXI. Rio de Janeiro: Nova Fronteira, 1998, p. 80.

? Vogt, C., Fry, P. Cafundo: A Africa no Brasil. Campinas: Editora da UNICAMP, 1996, p. 71.
} 
propriedade, em troca, presume-se de trabalho e submissão" ${ }^{8}$. Uma terceira característica destacada pelo autor é o fato de a maior parte dos doadores não possuir cônjuges ou herdeiros diretos.

A doação aqui trabalhada é retirada do isolamento. A semelhança com as características descritas por Slenes evidencia o testamento como produto destas relações de dependência. As palavras de Mariano Cardozo expressam perfeitamente a lógica aqui discutida:

Declaro que a minha mulher Rosa Ferreira dos Santos gozará do usufruto dos bens que the couber durante a sua vida e depois de seu falecimento serão divididos a meus escravos com igualdade com a condição de bem servirem durante a vida do último do casal e se assim não o fizerem perderão esse direito ${ }^{9}$.

É uma doação condicional e, curiosamente, o testamento não fala em momento algum sobre a alforria destes escravos. Eles continuam, portanto, obrigados a servirem sua senhora e quando esta morrer, terão o direito aos bens. E mesmo aqui não é referida a liberdade destes.

A noção chave para se compreender melhor tudo o que está sendo aqui exposto é a de patriarcalismo, ou paternalismo. Segundo Eugene Genovese,

o paternalismo definia o trabalho involuntário dos escravos como uma legitima retribuição à proteção e à direção que lhes davam os senhores. No entanto, a necessidade que tinham estes de ver seus escravos como seres humanos aquiescentes constituía uma vitória moral para os próprios escravos. A insistência do paternalismo em obrigações mútuas - deveres, responsabilidades e, em última instância, até direitos - representava, implicitamente, a humanidade dos escravos ${ }^{10}$.

O paternalismo para o autor moldou o mundo de senhores e escravos, com cada um interpretando-o a seu modo. A obra de Genovese gerou diversos debates e influenciou boa parte da produção brasileira. Entretanto, algumas diferenças centrais em relação à sociedade brasileira faz com que este paternalismo tenha algumas conseqüências distintas. O que se precisa ser referenciado é o caráter "plástico" da sociedade brasileira,

\footnotetext{
${ }^{8}$ Ibidem, p. 71.

${ }^{9}$ processo JP116, caixa 117

${ }^{10}$ GENOVESE, E. A terra prometida: o mundo que os escravos criaram. Rio de Janeiro: Paz e Terra, 1988, p.23.
} 
na qual a existência de uma mobilidade social é fundamental à estabilidade das relações hierárquicas aqui existentes. Como diz Hebe Mattos, "este movimento para livres ou escravos, não dependia apenas de seu sentido vertical, não se esgotava na incorporação, por dependentes ou escravos, de códigos exclusivamente senhoriais ou brancos. Sua plasticidade lhe permitia apropriações diversas. Apropriações que dependiam de coesões horizontais e potencializavam, daí sua força e efetividade" ". Voltaremos a este ponto.

$\mathrm{O}$ debate sobre paternalismo e mobilidade está, em boa parte, ligado às discussões em torno das possibilidades de existência da família escrava. No Paraná esta discussão é importante também para explicar certas peculiaridades da população escrava da região. Já é um fato reconhecido pela historiografia brasileira o fato de que escravos formaram familias estáveis. Como constatou Horácio Gutierrez, em um artigo escrito no final da década de 80 , os escravos do Paraná em fins do século XVIII e princípios do XIX eram predominantemente crioulos e apresentavam uma média de crescimento considerável. A taxa de crescimento era de $1,2 \%$ ao ano, variando, entretanto, de área para área, para o período de 1798 a 1830 12. Tal índice chama a atenção pelo fato de que o Paraná sempre teve uma tímida participação no tráfico atlântico de escravos. Daí a maciça presença de crioulos - escravos nascidos em solo brasileiro - entre a população cativa. Se o crescimento apontado não pode ser explicado pela injeção de novos cativos através do tráfico, uma forte hipótese é a reprodução natural destes escravos, o que, por sua vez, nos leva a pensar a família escrava.

Em 1830, a porcentagem de cativos casados no Paraná é de aproximadamente $1 / 5$ do total de escravos, segundo Gutierrez e Costa, ao passo que $79,6 \%$ são solteiros e viúvos compõem $2,9 \%{ }^{13}$.

Como trabalho aqui com um período bem posterior ao de Gutierrez, algumas mudanças são importantes de serem mencionadas, mas ainda assim sua reflexão é de grande utilidade. A partir de 1850 o tráfico atlântico de escravos é proibido e há um recrudescimento do tráfico interno. Isto terá algumas conseqüências sobre a população escrava paranaense como veremos mais adiante.

\footnotetext{
11 MATTOS, op. cit., p. 143.

12 GUTIERREZ, H. Crioulos e africanos no Paraná, 1798-1830. Revista Brasileira de História, v. 8, n. 16, mar/ago 1998 , p. 163.

${ }^{13}$ COSTA, I. N., GUTIERREZ, H. Nota sobre o casamento de escravos em São Paulo e no Paraná, (1830). História: questões e debates, N. 9, dez 1894.
} 


\section{Listas de Classificação:}

No processo que aqui analiso, é curioso observar que a escravaria de Mariano Cardozo e sua mulher se constituía basicamente de uma família nuclear, com exceção da escrava Maria. Gabriel e Vicência eram formalmente casados e com um filho, José. Um documento interessante para se trabalhar e observar a existência da família cativa no Paraná são as listas de classificação.

$\mathrm{O}$ artigo 3 da Lei Rio Branco visava o estabelecimento de um fundo de emancipação buscando libertar escravos através de rendas obtidas com impostos em torno de escravos, multas, loterias nacionais entre outros meios. Tal medida também demandava a constituição de juntas de classificação em cada município para levantarem as listas de classificação. Estas listas eram baseadas nas matrículas de escravos, obrigatórias a todos os senhores sob a pena de liberdade para os escravos que delas ficassem fora. As listas eram organizadas visando a libertação dos escravos, dividindo-se em duas partes. A primeira era relacionada aos escravos casados e seguia a seguinte ordem de preferência: (1) escravos casados pertencentes a senhores diferentes; (2) cônjuges com filhos libertos pela lei e menores de 8 anos; (3) cônjuges com fillhos livres menores de 21 anos; (4) cônjuges com filhos menores escravos; (5) mães com filhos menores escravos; e (6) cônjuges sem filhos menores. Na segunda parte eram listados os escravos solteiros, primeiro vindo mãe ou pai solteiros com filhos livres e, por fim, individuos entre 12 e 50 anos de idade, a começar pelos mais novos do sexo feminino e os mais velhos do sexo masculino ${ }^{14}$.

As listas nos fornecem dados interessantes que deixam mais do que claros a existência de famílias entre a população cativa paranaense. $\mathrm{O}$ ano que trabalharei aqui é o de 1975, ano em que foi produzida uma lista para Curitiba e seu entorno, estando presentes os municípios de Campo Largo, Votuverava, Arraial Queimado, São José dos Pinhais, Iguaçu e a própria capital, na lista. Na primeira parte, relativa aos cônjuges, a lista de classificação para a região de Iguassú, já que é a localidade na qual se desenrola o processo aqui discutido, apresenta 11 pessoas casadas de um total de 104. Isto significa dizer que aproximadamente $10 \%$ da população cativa era oficialmente casada. Um índice extremamente alto se

${ }^{14}$ CONRAD, R. Os últimos anos da escravatura no Brasil 1850-1888. Rio de Janeiro: Civilização Brasileira, 1975, p. 132-134.

PENA, E. S. O jogo da face: a astúcia escrava frente aos senhores e a lei na Curitiba provincial. Curitiba: Aos Quatro Ventos, 1999, p. 335-336. 
considerarmos o fato de que a oficialização das uniões conjugais estava sendo negligenciada neste contexto pelos senhores.

Esta questão sobre os casamentos sancionados pela Igreja foi longamente discutida por Robert Slenes em sua tese de doutorado. $\mathrm{O}$ autor argumenta na direção de que três fatores podem influenciar nas taxas de matrimônios sancionados: culturais, institucionais e sócio-econômicos. Entretanto, os dois primeiros têm maior influência nas regiões de plantation das províncias do Rio de Janeiro e São Paulo. Considerando toda a região do Brasil na década de 70, Slenes vai dizer que os fatores sócio-econômicos são a principal forma de explicar as altas ou baixas taxas de casamento ${ }^{15}$. O autor vai então desenvolver alguns esquemas com dois pólos ideais da escravidão brasileira que servem como um bom instrumento para compreendermos a situação na qual o Paraná se encaixa neste período de 1873-87. Portanto, nas regiões em que a importância da agricultura de plantation é alta, tende a ser alto o recebimento de cativos no tráfico interno, bem como as mulheres com casamentos, o que diz sobre o número geral de casamentos legalmente sancionados entre cativos. Onde a agricultura de plantation não é central, que é o caso do Paraná, o tráfico de cativos é alto, mas como fornecedor, e as taxas de casamentos legais são baixas. Uma das conclusões a que chega o autor, e que nos interessa aqui, é o fato de que os senhores ao promoverem casamentos entre seus cativos estariam limitando seu poder de dispor de sua propriedade para a venda no tráfico interno ou qualquer outro esquema que pudesse separar a família ${ }^{16}$.

Se considerarmos os laços de parentesco, e não apenas os matrimônios, os números oriundos da lista de classificação se alargam. Considerando todos os cativos que aparecem na lista com alguma menção na categoria "pessoas de família" (irmãos, filhos, etc), o número sobe para 64. Onze casos estão ilegíveis, mas é claro tratar-se de referência a algum parente. Pode-se afirmar, então, que a maioria dos cativos tinha algum vínculo familiar. $O$ numero de escravos que aparecem sem nenhuma menção a parentes é de 43 .

Portanto, não cabe pensar que o fato de haver poucos casamentos legais seja sinal da ausência da família escrava. Se por um lado, como vimos, não era do interesse dos senhores neste momento legalizarem uniões, por outro, certas características das próprias atividades desenvolvidas no campo paranaense podem estar influenciando na possibilidade da família

${ }^{15}$ SLENES, R. The Demography and Economics of Brazilian Slavery: 1850-1888 p. 426.

${ }^{16}$ Ibidem, p.442. 
escrava. Apesar de haver a coleta de erva mate, e escravos envolvidos na mesma, uma boa parte, senão a maior, estava envolvida em uma produção de alimentos cujos excedentes eram destinados ao abastecimento interno. Estes produtores eram pequenos produtores ou um campesinato que poderia recorrer ao trabalho escravo. Iguaçu, de todas as localidades da Comarca de Curitiba, é a que tem o maior índice de concentração de escravos: 4,2 cativos por proprietário ${ }^{17}$. Um número ainda assim pequeno que ressalta a predominância dos pequenos proprietários de escravos. Acredito estar próxima desta qualificação a unidade de Mariano Cardozo. A lógica chayanoviana de uma busca constante por um equilíbrio entre o número de trabalhadores e consumidores podia estender-se aos escravos. Como diz Hebe Mattos, "a dispersão precoce dos filhos tornava os cativos, freqüentemente, e em pouco tempo, simples substitutos daqueles" ${ }^{18}$. O que dizer do caso de Mariano Cardozo, que não possui qualquer filho? A busca por trabalhadores de acordo com as possibilidades de cultivo da terra pode ter incentivado a formação e estabilidade da família sob suas ordens. Afinal, seus cativos eram basicamente uma família, se excetuarmos a escrava Maria. A família escrava poderia aparecer, à primeira vista, neste contexto, não como um elemento criador de uma hierarquia no cativeiro, como alguns autores bem demonstraram para outras regiões ${ }^{19}$, mas como uma decorrência natural e desejável do tipo de produção a que estava vinculada a unidade doméstica de Mariano. Entretanto, estamos caminhando no terreno das hipóteses. As informações sobre o cotidiano destas pessoas antes da morte do senhor são escassas em nossa fonte, podendo vir a ser confirmada ou alterada no decorrer da pesquisa ao cruzarmos com outras fontes.

As listas podem, entretanto, fornecer algumas pistas ainda sobre este assunto. Encontramos na lista de 1875, tanto o casal Gabriel e Vicência, quanto a escrava Maria. Gabriel e Vicência, oficialmente casados, vêm antes na lista e com a observação "os escravos Gabriel e Vicência serão livres condicionalmente". E é importante notar que no caso de Maria, nada vem escrito na parte de observações. Entretanto, vimos que Mariano Cardozo destinaria sua herança a ser dividida igualmente entre seus escravos. Porque motivo estaria aparecendo à alforria condicional apenas para a família cativa, ao passo que à escrava solteira nada é referido? Talvez seja um indício de que a família escrava pode estar funcionando como um

\footnotetext{
${ }^{17}$ PENA, op. cit. p. 36.

${ }^{18}$ MATTOS, op. cit., p. 63.

${ }^{19}$ FLORENTINO, M, GOES, J. A paz nas senzala: familias escravas e tráfico atlânticos, Rio de Janeiro, c.1790-c.1850. Rio de Janeiro: Civilização Brasileira, 1997.
} 
fator hierarquizante, mesmo se tratando de um ambiente de pequenos plantéis, como é o caso do Paraná.

Uma última observação em relação às listas diz respeito às ocupações dos cativos. Gabriel, Vicência e Maria aparecem como cozinheiros, o que nos leva a relativizar as separações entre cativos domésticos e aqueles envolvidos na lavoura. Há uma tendência a separações bruscas, por parte dos pesquisadores, entre o cotidiano de escravos urbanos e rurais, como discutiremos mais a frente, bem como entre escravidão doméstica e aquela relacionada à outras atividades como agricultura ou criação de animais. Como veremos mais adiante, busco argumentar na direção de que pode haver um projeto camponês influenciando nas migrações dos cativos presentes no caso aqui discutido. Entretanto, o fato de observar isso em escravos classificados como domésticos nos obriga a relativizar estas separações brutais. Mesmo sendo categorizados como domésticos, não implica que estes não estavam envolvidos em outras atividades, o que leva a considerar que os limites não eram assim tão bem definidos. Se no caso da escravidão urbana, vemos muitos cativos sendo empregados no campo ${ }^{20}$, que dizer deste ambiente eminentemente rural? O cativo em uma unidade destas, apesar de aparecer como cozinheiro, estava, provavelmente, envolvido em diversas outras atividades, principalmente se lembrarmos que em nosso caso, especificamente, trata-se de uma senhora viúva e sem quaisquer filhos.

\section{Comparando casos:}

Doações semelhantes à de Mariano ocorreram na história do Paraná. Comparar a que está aqui sendo discutida com outros casos pode ajudar a entender certos aspectos de nosso objeto.

Neste sentido, o caso da invernada Paiol de Telha é extremamente útil. O testamento de Balbina Francisca de Siqueira concretizava alforrias prometidas anos antes por seu marido, Manoel Ferreira dos Santos. Dizia ela em seu testamento,

Declaro que os escravos que meu finado marido deixou como libertos, com a condição de me servirem durante a minha existência são os seguintes: Heliodoro e sua mulher Feliciana, Manoel, José Velho, José dos

\footnotetext{
${ }^{20}$ LIMA, C.A.M. Efetivo cativeiro: sobre a escravidão urbana e o artesanato escravista na América Portuguesa. (c.1700-c.1850). In: LIMA, C.A.M, MOURA, A. M. S.M, (orgs) Rio de Janeiro - tempos, espaço e trabalho. LEDDES, p. 172.
} 
Santos, Izidoro, Eduardo, Dinna, Joaquim, Libânia, Rita, os quais todos me prestaram bons serviços, ficão por isso gozando de liberdade ${ }^{21}$.

A primeira coisa a ser observada é o caráter condicional que seu falecido marido havia imposto à alforria de seus escravos. Estes só estariam livres após bem servirem a esposa. Condição semelhante à imposta por Mariano Cardozo a seus escravos, o que leva a pensar tal alforria como um reforço da idéia de um sistema de incentivos senhoriais.

A presença das três principais características destacadas por Slenes em seu estudo sistemático de testamentos, também se faz aqui presente. Os doadores não tinham herdeiros diretos. Não haviam tido filhos durante seu matrimônio. Em segundo lugar, o fato dos escravos possuírem famílias. Oficialmente casados havia apenas um casal no plantel de Balbina, que menciona na lista de libertos, Heliodoro e Feliciana. Entretanto, como já mencionado, o fato de existirem poucos matrimônios sancionados não deve fazer com que se interprete a ausência de famílias estáveis entre os cativos. A doadora está indo além de seu marido, e cedendo agora as terras a ela pertencentes. Neste momento do testamento, a senhora nos dá uma dica em torno da existência da família escrava além daquelas reconhecidas oficialmente:

Declaro que a Invernada, denominada Paiol de Telha, que possuo na fazenda Capão Grande e que principia desde o Portão até o Rio Reserva, com todas as terras de cultura nela existentes, ficão pertencendo, por meu falecimento, a todos os escravos acima mencionados e suas familias nella morarem, sem nunca poderem dispor, visto como fica como patrimônio dos mesmos ${ }^{22}$.

As terras ficam, portanto, a todos escravos e suas famílias. Famílias que podem ser compostas com cativos de outros senhores, com livres, e, provavelmente, não sancionadas. Mas ainda assim existentes, o que leva a serem mencionadas no testamento. E a terceira constante observada por Slenes em seus testamentos, pode ser encontrada na citação acima também. O fato de os escravos nunca poderem dispor de suas terras. Esta é uma preocupação do senhor em relação ao ex-escravo, buscando proibir que este aliene sua propriedade. Como diz Slenes, "o doador tomava

${ }^{21}$ ABREU, A. T. G., MARCONDES, G.G. Escravidão e trabalho. Paraná: Unicentro, 1991, p. 284 .

${ }^{22}$ Ibidem, p. 284. 
o cuidado de limitar o poder dos legatários de alienar a propriedade, numa clara tentativa de protegê-los "contra si'" ${ }^{23}$.

Excetuando esta última característica, é clara a semelhança do testamento de Balbina com o de Mariano Cardozo. Ambos sem filhos, com alforrias condicionais, e plantéis com famílias constituídas.

Vale ainda chamar a atenção para um último aspecto da doação de Balbina. Após a morte de seu marido, a senhora comprou ainda dois cativos.

Declaro que depois do falecimento de meu esposo possui mais dois escravos, sendo estes: José Marcos, meu afilhado, e Generosa, dos quais fica liberto, sem mais condição alguma, o dito José Marcos, e fica também liberta a mesma Generosa, com a condição porém de servir por espaço de quinze anos as órfãs que estou criando de nomes: Maria Antonia dos Santos e Porfíria Pedra, das quais se alguma casar, fica ela servindo à que ficar solteira, e dela não poderá retirar-se sem completar os quinze anos, contados do dia de meu falecimento ${ }^{24}$.

Se por um lado os escravos que haviam cumprido a condição imposta pelo falecido marido de Balbina alcançavam enfim a liberdade incondicional, o mesmo não se podia dizer de sua escrava Generosa, que agora se via na condição de servir por quinze anos as órfãs. Qual teria sido a reação dos outros escravos se a senhora decidisse impor agora uma nova condição? Provavelmente resistência, pois a outra face do paternalismo era, como argumenta Genovese, o fato de que os escravos se apropriavam deste mesmo paternalismo e o transformavam em uma arma ao conseguirem fazer reconhecer seus direitos duramente conquistados no cotidiano da escravidão 25. Dessa forma, as novas condições caem sobre a cativa que chegou depois ao plantel de Balbina e não estava entre os mencionados no testamento de seu marido.

Curiosamente, o outro escravo adquirido após a morte do senhor Manoel teve declarada liberdade incondicional e era afilhado de Balbina. Teria este compadrio influenciado na declaração testamentária? Analisando batismos em Curitiba, Stuart Schwartz chega a conclusão de que eram raros os senhores que batizavam seus escravos, predominando entre estes últimos o estabelecimento de laços de compadrio com pessoas livres sem qualquer

\footnotetext{
${ }^{23}$ VOGT, FRY, op. cit., , p. 71

${ }^{24}$ ABREU, A. T. G., MARCONDES, G.G. op. cit., p. 284.

${ }^{25}$ GENOVESE, op. cit., p. 25.
} 
parentesco com os senhores. Entretanto, apesar de serem exceções, aparecem alguns batismos realizados por senhores, e é o caso de Balbina e seu afilhado José Marcos. Schwartz comenta, ao analisar seus dados, que "para os escravos, esses padrões indicam a aceitação das circunstâncias e a tentativa de usar a instituição do compadrio para melhorar a própria situação ou fortalecer laços de família" ${ }^{26}$. Portanto, ainda que uma exceção, o compadrio de senhores devia indicar a mesma estratégia por parte dos escravos em buscar melhorar a condição, e no caso de José Marcos, com sucesso.

Ainda que o fato de ser um período de desagregação da escravidão esteja influenciando certos acontecimentos, tais doações não podem ser meramente atribuídas a isto, como estou procurando mostrar. Tais práticas eram comuns ao sistema escravista, e por mais que estejam sendo influenciadas por esta condição de crise, sempre existiram e estão ligadas mais à sua estruturação que o inverso.

Um caso de fins do século XVIII na freguesia de Santa Anna do Yapó, futura vila de Castro, é interessante de ser aqui discutido por também guardar certas semelhanças com o caso aqui analisado. Adriano Lima, utilizando este caso como pontapé inicial de sua dissertação de mestrado, nos fornece sua descrição. Partindo da alforria concedida em 1794 em um livro de notas, o autor cruza estes dados com listas nominativas de habitantes e consegue reconstituir importantes aspectos das trajetórias destes cativos. A viúva Catarina de Oliveira concedia a alforria a oito escravos seus. Estes cativos eram filhos da já falecida preta Paula, alguns dos quais filhos de uma antiga união com Sebastião Sutil, falecido marido de Catarina de Oliveira.

$\mathrm{Na}$ lista nominativa de 1776 aparecem três dos filhos de Paula como escravos de Catarina. Entretanto, a descrição dos escravos é o que chama a atenção. Felipe Sutil, por exemplo, residia em um domicílio com sua esposa e seus quatro filhos no mesmo bairro de sua senhora, cuidava de sua roça - naquele ano plantou "hu alqueire de milho e meyo de feijão" 27 e trabalhava com tropeirismo. Seu irmão, Francisco Sutil, residia ao lado, casado e com cinco filhos também possuía uma roça e era envolvida na condução de tropas. A seis casas dali residia a Ignes Sutil, irmã dos outros

\footnotetext{
${ }^{26}$ SCHWARTZ, S. Escravos, roceiros e rebeldes. São Paulo: Edusc, 2001, p. 285.

${ }^{27}$ LIMA, A.B. M. Trajetórias de crioulos: um estudo das relações comunitárias de escravos e forros no Termo da Vila de Curitiba (c. 1760 - c. 1830). Dissertação de mestrado, UFPR, 2001 , P. 24.
} 
dois. Também casada, com sete filhos, uma roça de milho e feijão e o marido trabalhando igualmente com tropeirismo.

A semelhança entre os três está no fato de possuírem famílias, roças, e, enfim, de terem conseguido aproximar-se da condição de homens livres pobres. Conseguiram se aproximar de uma experiência de liberdade. $\mathrm{O}$ caso reforça a existência da família escrava, e por ser em um período distinto daquele em que se situa meu estudo, reforça sua existência de tempos coloniais. Agora, um aspecto que julgo central neste caso é a existência desta mobilidade entre escravos rurais. A historiografia normalmente atribuiu a mobilidade a aos escravos urbanos ao passo que os cativos do campo estariam relegados a condições mais duras e estáticas.

É importante retomar aqui esta discussão para melhor compreender tanto o tipo de mobilidade com que podemos estar nos deparando no caso dos Sutil, e no caso dos escravos do falecido Mariano Cardozo. Mas, também, para que se possa colocar a noção de autonomia, que os escravos podiam adquirir, entre aspas, bem como ressaltar a idéia de que as relações no campo não estiveram tão diametralmente opostas às do cativeiro urbano. Carlos Lima, trabalhando com inventários post-mortem de princípios do século XIX, traz alguns apontamentos interessantes de serem aqui discutidos. O autor argumenta na direção de que as atividades que caracterizam o cativeiro urbano seriam todas marcadas por esquemas rentistas. O trabalho artesanal escravo era, por exemplo, bastante semelhante ao aluguel de cativos a artesãos com uma certa especialização. A pretensa autonomia torna-se mais uma variante na forma de extração de renda. Como diz o autor, "a mera propriedade gestava a rentabilidade" 28. Não a toa os artesãos eram os mais valorizados no mercado e o aparecimento de cativos envolvidos com estas atividades artesanais foram muito maiores em períodos de alta econômica. Inversamente, em períodos de retração os escravos de "ganho" têm maior peso, abstraindo aqueles envolvidos em serviços domésticos, que eram a maioria dos escravos urbanos na América Portuguesa.

Vale a pena nos determos com mais atenção no "ganho". A atividade que deu margem para se pensar uma autonomia escrava era exatamente esta exercida pelos escravos de "ganho", que eram cativos envolvidos com transporte e comércio, e que conseguiam, por isto, ter uma grande circulação. Como já mencionado, cativos envolvidos com o "ganho" apareceram na documentação com maior peso em períodos de

${ }^{28}$ LIMA, C.A.M., op. cit., P. 177. 
retração do mercado. A interpretação do autor é de que "a circulação urbana do cativo constituía recurso de oportunidade do senhor, apto a permitir-lhe lidar com um mercado retraído, próprio dos períodos de dificuldades econômicas, apelando para a capacidade autônoma dos cativos para produzir ganhos" ${ }^{29}$. A circulação de cativos responde a um mecanismo de extração de rendas cuja conjuntura econômica acaba por forçar os senhores a utilizar.

A mobilidade destes escravos de "ganho" é interessante para pensarmos a fonte aqui discutida. A possibilidade que estou buscando apontar é a de que o momento de crise econômica pode estar criando uma situação semelhante à descrita anteriormente, em que o senhor passa a contar com a "autonomia" de seus cativos para conseguir extrair alguma renda. No período em que se passa o processo aqui analisado, algumas das principais atividades desenvolvidas no Paraná estão em franco declínio, como o tropeirismo. Entretanto, no caso descrito no trabalho de Adriano Lima, já mencionado, o contexto não é de crise. O que complica ao mesmo tempo em que enriquece esta questão da mobilidade no campo. Se no cativeiro urbano, períodos de retração correspondiam ao aumento do "ganho" ao passo que em momentos de alta econômica a atividade artesanal exercida por escravos era maior, no caso do mundo rural paranaense somos obrigados a pensar estas situações de uma forma diferente. $\mathrm{O}$ fato de Castro na época ser região de fronteira aberta pode estar influenciando na existência desta mobilidade em um periodo de alta.

$\mathrm{Na}$ fonte aqui estudada, o contexto é de crise, como já referido. O que pode explicar certos aspectos do processo. Os fatos que decorrem após a morte do senhor Mariano Cardozo são relatados de forma semelhante nos depoimento da senhora e das testemunhas: primeiro saem da companhia de sua senhora o casal Gabriel e Vicência, seguidos de seu filho, e por fim a escrava Maria. Jozé Luiz de Andrade, um negociante de Iguassú, é a primeira testemunha a depor no processo diz que sabe por ser notório que "os ditos réos se retirarão da companhia da autora, que então era ainda viúva, deixando de prestar-lhe serviços e não mais voltarão a sua companhia, sendo que primeiramente retirou-se Gabriel com sua mulher depois seu filho José e por ultimo a preta Maria" ${ }^{30}$. Em momento algum de seu depoimento, ou de todos os outros, a retirada dos cativos é mencionada como uma fuga. Tanto que no momento de abertura do processo o local de

\footnotetext{
${ }^{29}$ Ibidem, p. 173.

${ }^{30}$ processo JP116, caixa 117.
} 
residência dos ex-escravos é plenamente conhecido e estes são intimados ao comparecimento.

O que intriga na leitura do processo é que além da palavra fuga não ser mencionada uma única vez, não foi realizada qualquer tipo de mobilização para que estes cativos retornassem para o lado de sua senhora. A ausência da menção à fuga ou qualquer idéia deste tipo pode ser decorrência do fato de que o processo é aberto após a abolição da escravidão, apontando para um discurso que busca se livrar de um jargão escravista. Por outro lado, uma situação como a que venho tentando argumentar pode ser uma explicação. Esta retirada dos cativos poderia ser uma conseqüência da pobreza e crise, como uma tentativa da senhora de conseguir renda com a capacidade de seus cativos de se estabelecerem em terra livre. Aqui a situação de fronteira aberta é fundamental, bem como o fato de que é uma família que se retira para outra região, ao passo que a escrava solteira fica na própria região de Iguassú. É uma situação muito semelhante à conclusão que chega Carlos Lima em seu estudo sobre o cativeiro urbano: "Senhores (normalmente senhoras) extremamente empobrecidos tornando-se dependentes dos recursos obtidos na 'autonomia' da circulação pelas ruas a um ponto tal que posições de autoridade poderiam ver-se comprometidas" 31 .

Um fator que complica o argumento até aqui utilizado é o fato de que o escravo Gabriel, antes de se retirar, furta uma vaca do vizinho de sua senhora. Testemunhou José Luz de Andrade que "sabe, por ter ouvido dizer que Gabriel furtara uma vaca à Francisco de Paula Câmara quando ainda se achava em companhia da autora a qual indenizou o mesmo Câmara" 32. Entretanto, o fato da senhora entrar com um processo apenas depois de quase 10 anos para reclamar das atitudes de seus escravos torna o caso ainda instigante. A dúvida permanece: porque não há qualquer mobilização para a busca destes cativos? Ainda sabendo que um deles havia cometido um furto e normalmente passaria por algum tipo de castigo. $\mathrm{O}$ roubo da vaca pode vir a reforçar, portanto, as idéias desenvolvidas anteriormente. Se por um lado o furto do animal dizia respeito à estratégias de sobrevivência do cativo, é fato também que pode estar apontando para a pobreza da região, em especial da unidade composta pela senhora Rosa e seus cativos. A opção pela renda através da capacidade autônoma de seus cativos nos parece uma forte possibilidade a ter sido posta em prática.

\footnotetext{
${ }^{31}$ LIMA, C, op. cit., p. 198.

${ }^{32}$ processo JP116, caixa 117.
} 
É importante pensar que este mecanismo não era simples estratégia senhorial. Ele pode estar ligado, como vimos, a flutuações do mercado e é ilusório imaginar que os escravos entravam no esquema fazendo-o funcionar com perfeição. Estes teciam suas próprias expectativas' e poderiam responder de forma diferenciada a situações como esta. Como vimos, os cativos de Rosa "retiraram-se da companhia da suplicante, para não the prestarem, como não prestaram serviço algum, depois de the causarem graves incômodos e prejuizos" ${ }^{33}$.

$\mathrm{O}$ fato de Gabriel ser auxiliado por um livre pode indicar a perda de legitimidade que a escravidão vinha tendo face aos homens livres e como esta influencia os ocorridos. Desde a proibição do tráfico, a concentração de cativos nas mãos de menos senhores, faz com que a escravidão vá perdendo a credibilidade. Antes de 1850, a posse de cativos era pulverizada, o que tornava a sociedade fortemente comprometida com a permanência da escravidão. Libertos conseguiam facilmente ter acesso a escravos, o que impossibilitava qualquer surgimento de um movimento mais amplo rechaçando a instituição. Com a concentração da posse, o preço do escravo torna-se acessível a poucos senhores criando esta situação. Assim pode-se compreender uma relação entre um escravo e um livre no roubo da vaca. Há ainda a possibilidade de que Lourenço de Jesus, o livre a ajudar Gabriel, seja um liberto. Testemunha Eduardo Cardozo, sobrinho de Mariano Cardozo, lavrador casado, residente em Iguassú, com 48 anos, que

ouviu dizer que Gabriel, réu nesta causa, juntamente com Lourenço de Jesus, furtaram uma vaca à Francisco de Paula Câmara, a quem a autora indenizou e que além deste a autora se queixava de incômodos que the causavam os réus quando em sua companhia.

Na lista de classificação de Iguassú, aparece em 1875 um cativo chamado Lourenço, pertencente à senhora Maria Eufrazia de Jesus. Seria um liberto usando o sobrenome de sua ex-senhora? Fica levantada aqui a hipótese.

De qualquer forma há uma relação entre um cativo e um homem livre e esta se revestia de um significado especial neste período final da escravidão. Como diz Hebe Mattos,

por mais que a potência da propriedade continuasse a afastar os homens livres do mundo dos escravos, a crescente convivência entre livres pobres,

${ }^{33}$ processo JP116, caixa 117. 
forros e cativos, próprios ou de outrem, aliada às crescentes pressões sobre as possibilidades de ascensão social dos homens livres, na segunda metade do século XIX, acabou por determinar uma intensa interação cultural dos dois grupos, sobreposta, de fato, à identidade senhorial que até então se procurara emprestar à liberdade ${ }^{34}$.

A identidade senhorial da qual fala a autora é o fato de que no período anterior a 1850, os libertos buscavam se distanciar de uma imagem do escravo e para isso muitos buscavam a propriedade de escravos, além de terras e demonstrar uma certa mobilidade. As duas últimas características serão as que se acentuarão com o fim do tráfico. A liberdade tinha um forte significado de aversão ao trabalho para outrem, sendo este último relacionado com o cativo. Após o fím do tráfico, a já mencionada concentração de cativos nas mãos dos senhores mais ricos faz com que esta identificação com os senhores seja substituída, em boa parte, por uma identidade camponesa formada pela mobilidade e o trabalho temporário visando uma autonomia com trabalho familiar, diametralmente oposta a uma identidade escrava, marcada pela ausência de mobilidade e a obrigação de servir a um senhor.

Estas transformações terão algumas conseqüências sobre a população cativa. Muitos escravos buscarão com suas estratégias se aproximar dessa experiência de liberdade. Desta forma podemos compreender a migração da família escrava de posse de Rosa Ferreira. Pode ser que seja isso que estejamos observando aqui. A constituição de uma família, bem como a busca por acesso a terra, da perspectiva dos escravos era a forma com que podiam se aproximar do estatuto de livres, ainda que no caso aqui estudado, como vimos, alforria alguma tenha sido colocada. A migração não é, portanto, simples interesse senhorial, caso a hipótese de extração de renda com a capacidade de "autonomia" de seus escravos no período de crise seja válida, mas, também, fruto das próprias expectativas criadas pelos cativos e colocadas em prática.

Todos, à exceção da escrava Maria, migram a uma certa altura. Conforme os testemunhos e o relato da própria senhora, primeiro retiram-se Gabriel e sua mulher Vicência, depois o filho do casal, Jozé, e por fim, Maria. Esta última permanece na freguesia de Iguassú. O casal, seguido pelo filho - que se casa dali a alguns meses - retiram-se, provavelmente para a região de Rio Negro, próxima à Lapa. Nos relatos não há a menção

${ }^{34}$ MATTOS, op. cit. p. 102. 
dos destinos dos cativos, entretanto, quando o processo começa a rolar, os juízes sabem exatamente onde encontrar os ex-escravos de Rosa Ferreira. Inclusive esta última também migra. No momento do processo está residindo em Palmeira, já com um segundo matrimônio, o que também explica seus esforços para impedir que os bens da meação de seu falecido marido sejam entregues a seus ex-escravos após sua morte. Provavelmente já têm herdeiros mais importantes a quem direcionar estes bens.

No processo não há qualquer referência à atual situação dos exescravos, se possuem terras, etc. Entretanto, me parece bastante plausível que sua mobilidade tenha sido motivada por estas aspirações camponesas. Estas expectativas pode nos dizer muito sobre como se deu a transição do trabalho escravo para o livre e as trajetórias dos libertos antes e após a abolição.

\section{Depois do fim:}

O que o processo discutido pode dizer sobre o pós-abolição? Compreender as relações entre livres e escravos nas últimas décadas da escravidão, bem como as expectativas e aspirações de cada grupo, é crucial para se entender os acontecimentos após o fim da escravidão.

Foi uma idéia difundida por muito tempo entre os pesquisadores a noção de que os escravos fugiram das fazendas para as cidades brasileiras. Para o Paraná, por exemplo, Altiva Balhana e Cecília Westphalen argumentam que "esta camada da sociedade adquire novas funções depois da Abolição. Em geral, com a libertação, os escravos abandonaram em massa as fazendas e foram para as cidades" ${ }^{35}$.

Pesquisas vêm mostrando um forte desejo por autonomia entre os libertos antes e depois da abolição da escravidão em diversas regiões da América. Em Cuba, por exemplo, Rebecca Scott observou uma divisão crucial na ilha. A região ocidental era a mais comprometida com o trabalho escravo e que contava com a menor população negra livre. O oriente, por sua vez, sempre teve uma grande parcela de negros livre, e, dessa forma, muitos pequenos proprietários negros e mulatos. Após a abolição, a região oriental parecia ser um grande atrativo para os libertos buscando autonomia. Entretanto, o fato da área ter recebido muitos libertos durante a existência da escravidão, e um crescente atrelamento à produção açucareira, impediu a existência de um "campesinato reconstituido", como observou Sidney

\footnotetext{
${ }^{35}$ História do Paraná. P. 93
} 
Mintz para certas regiões do Caribe ${ }^{36}$. Segundo a autora, "a província mais empenhada na produção de açúcar e comprometida com o trabalho escravo - Matanzas - foi a área que mais se caracterizou pelo trabalho assalariado. A região menos comprometida com a escravidão e com o açúcar - o Leste foi à menos comprometida com o trabalho assalariado; onde em maior medida as adaptações camponesas e semicamponesas se desenvolveram" ${ }^{37}$.

O que a autora busca mostrar, é que não foi um simples processo de transição de escravo para camponês. O processo de transição para o trabalho livre em Cuba esteve marcado por diferentes conformações. A distribuição de terras esteve totalmente ligada à isto, e os escravos buscaram lutar por uma autonomia das mais variadas formas, fosse buscando firmarse em terras na parte oriental da ilha - tarefa cada vez mais complicada - ou mesmo permanecendo nas grandes plantações, mas lutando pela permanência dos conucos - pequenas roças cedidas ainda no período da escravidão. Muitos conseguiram, inclusive, dedicar-se exclusivamente a estas pequenas roças, afastando-se da grande produção açucareira.

Buscando pensar o processo de transição do trabalho escravo para o trabalho livre no Brasil, mais especificamente no Paraná, alguns apontamentos de Scott são interessantes de serem levados em conta. A existência de terras de fronteira aberta é fundamental para tentarmos compreender as trajetórias dos libertos após a abolição. Neste sentido, trajetórias dos últimos anos da escravidão - como a aqui analisada - podem estar nos fornecendo algumas pistas sobre isso. Somente uma pesquisa mais sólida, com uma documentação maior, pode nos dizer de fato se Rio Negro - o lugar que recebe a família de Gabriel e Vicência - é uma região de fronteira aberta nesse período final da escravidão e, talvez, após ela. Entretanto, regiões onde os libertos podem estar conseguindo firmar-se autonomamente podem existir no Paraná. A movimentação dos libertos em direção a estas áreas é a conseqüência lógica da existência de um projeto camponês entre os cativos e pode estar motivando muitos deles. É importante, porém, manter em mente que este desejo por autonomia provavelmente foi obrigado a adaptar-se às circunstâncias, podendo-se conjugar trabalho em parceria, ou o assalariamento, com a produção familiar em roças.

\footnotetext{
${ }^{36}$ SCOTT, R. Emancipação Escrava em Cuba. Rio de Janeiro: Paz e Terra; São Paulo: Editora da Universidade Estadual de Campinas, 1991, p. 247.

${ }^{37}$ Ibid, p. 266.
} 
Hebe Mattos diz o seguinte sobre os momentos após a abolição na região Sudeste:

nos meses posteriores a maio de 1888 , os últimos libertos não deixaram de conseguir força de pressão - pela carência de mão-de-obra - para realizar algumas de suas expectativas de autonomia de trabalho e acesso à terra, influindo, especialmente, para a predominância do trabalho familiar nas relações de parceria e colonato. A organização do trabalho coletivo no eito, que os ex-senhores tentaram manter, mas que foi fortemente rejeitada pelos últimos escravos e também pela população pobre nascida livre no meio rural, praticamente não teria continuidade após o 13 de maio ${ }^{38}$.

Cabe agora pensar como se deu este processo no Paraná. Como já mencionado, a região não era marcada pela produção de plantation, mas sim por pequenas unidades produtivas, pequenos plantéis de escravos, em suma, uma produção em grande parte camponesa. Claro que houve grandes plantações e plantéis maiores, mas a pequena produção de alimentos parece ter dado o tom das atividades, ao lado da colheita de erva-mate. Estas especificidades da região podem ter influenciado tanto no mercado de terras, quanto nas trajetórias pós-abolição e é importante tê-las em mente para melhor compreendermos como se configuraram as relações de trabalho.

\section{Considerações finais:}

No que pode auxiliar uma fonte como a que ocupou o centro do presente trabalho? A idéia não é a de apontar para respostas sólidas, mas indicar certas possibilidades como o fizemos. As pesquisas sobre a escravidão e seu fím no Paraná, aumentam, e minha intenção foi aqui a de enriquecer os debates buscando atentar para as especificidades da região e, quem sabe, revelar aspectos que escapariam às analises mais gerais.

O que observamos com a bibliografia relativa a outras regiões, é que áreas como o Paraná, cuja produção não é predominantemente a plantation agro-exportadora, certas situações peculiares podem surgir. $\mathrm{O}$ que vimos no caso aqui discutido, contraposto a outros, fói uma fronteira

\footnotetext{
${ }^{38}$ MATTOS, H. M. Campesinato e escravidão. In: In: Francisco Carlos Teixeira da Silva, Hebe Mattos e João Fragoso (orgs.). Escritos sobre História e Educação, em homenagem a Maria Yedda Leite Linhares.
} 
borrada entre escravidão e liberdade, uma certa indefinição em relação ao estatuto dos cativos, para o que levantei algumas hipóteses.

Há ainda muita pesquisa a ser feita em relação à escravidão paranaense e seu estudo pode dizer muito sobre o cativeiro em regiões menos ligadas à agro-exportação nas Américas.

\section{Bibliografia}

CONRAD, R. Os últimos anos da escravatura no Brasil 1850-1888. Rio de Janeiro: Civilização Brasileira, 1975.

COSTA, I. N., GUTIERREZ, H. Nota sobre o casamento de escravos em São Paulo e no Paraná. (1830). História: questões e debates. N. 9, dez 1894.

FLORENTINO, M, GOES, J. A paz nas senzala: familias escravas e tráfico atlânticos, Rio de Janeiro, c.1790-c.1850. Rio de Janeiro: Civilização Brasileira, 1997.

GENOVESE, E. A terra prometida: o mundo que os escravos criaram. Rio de Janeiro: Paz e Terra, 1988

GUTIERREZ, H. Crioulos e africanos no Paraná, 1798-1830. Revista Brasileira de História, v. 8, n. 16, mar/ago 1998.

LEVI, G.A herança imaterial: trajetória de um exorcista no Piemonte do século XVII. Rio de Janeiro: Civilização Brasileira, 2000.

LIMA, A.B. M. Trajetórias de crioulos: um estudo das relações comunitárias de escravos e forros no Termo da Vila de Curitiba (c. $1760-$ c. 1830). Dissertação de mestrado, UFPR, 2001.

LIMA, C.A.M. Efetivo cativeiro: sobre a escravidão urbana e o artesanato escravista na América Portuguesa. (c.1700-c.1850). In: LIMA, C.A.M, MOURA, A. M. S.M, (orgs) Rio de Janeiro - tempos, espaço e trabalho. LEDDES.

MATTOS, H.M. Das Cores do Silêncio: os significados da liberdade no Sudeste escravista, Brasil Século IXI. Rio de Janeiro: Nova Fronteira, 1998. 
MATTOS, H. M. Campesinato e escravidão. In: In: Francisco Carlos Teixeira da Silva, Hebe Mattos e João Fragoso (orgs.). Escritos sobre História e Educação, em homenagem a Maria Yedda Leite Linhares.

PENA, E. S. O jogo da face: a astúcia escrava frente aos senhores e a lei na Curitiba provincial. Curitiba: Aos Quatro Ventos, 1999.

SLENES, R. The Demography and Economics of Brazilian Slavery: 18501888

ABREU, A. T. G., MARCONDES, G.G. Escravidão e trabalho. Paraná: Unicentro, 1991.

SCHWARTZ, S. Escravos, roceiros e rebeldes. São Paulo: Edusc, 2001

SCOTT, R. Emancipação Escrava em Cuba. Rio de Janeiro: Paz e Terra; São Paulo: Editora da Universidade Estadual de Campinas, 1991.

VOGT, C., FRY, P. Cafundó: A África no Brasil. Campinas: Editora da UNICAMP, 1996. 